\title{
Effect of Indigenous Rhizobacteria and Manure on the Growth and Yield of Red Potato (Solanum tuberosum L.) in Solok, West Sumatera
}

\author{
Indra Dwipa ${ }^{\#}$, Winda Purnama Sari", Warnita \\ ${ }^{\#}$ Department of Agronomy, Faculty of Agriculture, Andalas University, Padang, West Sumatera, 25163, Indonesia \\ E-mail: 1965indradwipa@gmail.com
}

\begin{abstract}
Potato is important food for half population of the world particularly population in Europe and America. Beside it is as carbohydrate source, potato can be used as main food for diabetes people, replaces the rice due to it contains low calories. In developed countries, particularly in Indonesia, it is also as diversify food for medium and highland people. The research was conducted in Selayo Tanang Buki Sileh, Lembang Jaya, Solok regency, West Sumatera, Indonesia from May to August 2017. The research aimed to study the interaction between indigenous rhizobacteria and manure to the growth and yield of red potato. The factorial design in Completely ranzomized design (CRD) with 2 factors was used in this reserach. The first factor was rhizobacteria isolates (no isolate, A2.1b2; A3.1a5; B1.2a2) and the second factor was the manure with dose 30 ton/ hectare (chicken, quail, and cattle). The potato variety that used in the assay was PING 06. The data was analyzed by analysis of variance with Honestly Significant Difference/HSD test in 5\%. Generally, the result showed that there was no interaction between rhizobacteria isolates and manure to growth and yield of red potato. A2.1b2 was the best isolate for fresh weight of tuber per plant, per plot and per hectare of red potato plant and chicken manure could increase the growth and yield of red potato plant (11.73 ton/hectare).
\end{abstract}

Keywords - growth; manure; potato; rhizobacteria; yield.

\section{INTRODUCTION}

Potato (Solanum tuberosum L.) is one of main food for several countries in Europe and America [1]. In Indonesia, it is priority plant to be developed because it has a fairly high economic value. Potato is a staple fourth foodstuff in the world after rice, corn, and wheat [2]. In Asia, potato was third place after rice and wheat. The demand of the potato in Indonesia is increasing, both as fresh products and processed products, as the position for the future potato expect other than used as a vegetable, as well as an option to diversify sources of carbohydrates which help strengthen food security [3]. In 100 gram, potato contains 347 calories, 85.6 $\mathrm{g}$ carbohydrate, $0.3 \mathrm{~g}$ protein, $0.1 \mathrm{~g}$ fat, $20 \mathrm{mg}$ calcium, 30 mg phosporus, $0.5 \mathrm{mg}$ iron and $0.04 \mathrm{~g}$ vitamin B [4]. Besides it, potato tuber also contains solanine, a toxic compund and it is dangerous for human and animals. This toxin can be removed by treating the tuber wisely [5].

Indonesia has wide potato production center and $25 \%$ of Indonesia area was potato plants. Several provinces were potato production center such as West Java, Middle Java, East Java, South Sulawesi, North Sumatera, Jambi, Aceh, Bengkulu and West Sumatera [6]. Production of potato in Indonesia in 2016 was $1,213,038$ ton with the productivity was 18.23 ton/hectare. In West Sumatera, the potato production was 5,583 ton with its productivity 19.49 ton per hectare [7]. Potency of potato production could be up to 40.98-43.30 ton per hectare. Generally, the nasional productivity of potato in Indonesia was still low if compared to other countries such as Australia (39.69 ton), United States (47.15 ton), Japan (30 ton) and Laos (30.04 ton). [6] The problems of potato production were low quality and quantity of tuber, the cultivation is still conventional, topography and Indonesia region is optimum place for potato pests and diseases development.

One of potato type that cultivated in Indonesia was red potato. Red potato has potential prospective business in the future. It contains natrium, vitamin $\mathrm{C}$ and $\mathrm{B} 1$, mineral, phosporus, iron and potassium [8]. Although many advances, its production is still limited. Red potato is still cultivated in Dieng highland, West Java, Bengkulu and Solok, West Sumatera. The productivity of red potato in Dieng is up to 30 ton per hectare, in Bengkulu 40-50 ton and in West Sumatera 15 ton per hectare [9].

Red potato was one of main commodity in Solok Regency. It is in second place after vegetables with land area up to 1,462 hectares [9]. Due to important, many efforts to increase the production of red potato in this region. One of technology used was the rhizobacteria application [11][12]. Rhizobacteria is bacteria group that lives saprophytically in 
rhizosphere and several of them as a plant growth promoter so that increases the yield of plant [13]. Rhizobacteria isolate can be as plant growth promoter or Plant Growth Promoting Rhizobacteria (PGPR)[14]. Previous reported that 2 indigenous rhizobacteria isolates were obtained, Pseudomonas genophilata and Bacillus pumilis [15]. Both of these could induce the resistance, enhance the growth and yield of shallot in planta. Furthermore, rhizobacteria could colonize the rhizosphere aggressively and several of rhizobacteria could as biofertilizer in plant [16].

Rhizobacteria could be found in rhizosphere of plant, a thin soil layer that covered root surface and posstively affected the plant growth [14][17]. It could be isolated from various plant rhizosphere such as cabbage, apple and soybean [18][19]. Rhizobacteria could be also isolated from Graminae plant such as Azotobacter paspali, Pesudomonas sp. and Beijerinckia sp. Azotobacter is a $\mathrm{N}_{2}$ fixer bacteria that can produce gibberellin, cytokinin and indole acetic acid, the compounds can stimulate root growth [20].

The other way to increase the growth and yield of potato is manure application. Manure is waste products from pet that can be used as nutrient plant, improves physic and biology of soil and supports the soil microorganism growth including the rhizobacteria in soil [21]. A report reported that 20-30 ton of manure were required to obtain high yield of potato. Other report reported that organic matter from chicken dung with dose 20 ton gave the best yield. The common manure used is cattle. Some advantages are it can improve soil structure and plays role as soil organic decomposer. Cattle manure also contains macro nutrients such as $\mathrm{N}, \mathrm{P}, \mathrm{K}_{2} \mathrm{O}$ and micro essential elements that required by plant [22]. The other pet waste can be used as manure is quail. Manure of quail is easy to be obtained and it contains high nutrients and easy to absorbed by plant. It contains macro elements $(\mathrm{Ca}, \mathrm{P}, \mathrm{N}$ and $\mathrm{K})$ and micro elements (Fe, $\mathrm{Cu}, \mathrm{Zn}, \mathrm{Mn}$ and $\mathrm{Mo}$ ) that required by plant. The quail manure decompose quickly and it directly can be absorbed by plant. The other report reported that quail manure contained $0,06-3,19 \%$ of $\mathrm{N}, 0,21-1,37 \%$ of $\mathrm{P}$ and $3,13 \%$ of $\mathrm{K}_{2} \mathrm{O}$. It is appropriate as manure for vegetable and ornamental plants [23].

The interaction between manure and rhizobacteria was an interested thing to study due to both of these could increase growth and yield of potato. The reserach aimed to study the interaction between indigenous rhizobacteria and manure to the growth and yield of red potato.

\section{MATERIAL AND METHOD}

The experiment was conducted in Selayo Tanang Bukit, Lembang Jaya, Solok regency, West Sumatera, Indonesia from May to August 2017. Factorial design in Conpletely randomized design (CRD) with 2 factors were used in this experiment. The first factor was rhizobacteria isolates with 4 treatments (without isolate, A2.1b2, A3.1a5 and B1.2a1). The variety of potato was PING 06. The isolates were the collection of Department of Agronomy, Faculty of Agriculture, Andalas University and they were the characterization result. A and B letters were the variety of red potato. Numbers after letters were the location of sampling in the field. The numbers and letters after (.) were the bacterial colonization that were chosen in one petri dish.
Numbers after lowercase were rejuvenation result and chosen as pure isolate. The second factor was the manure with 4 treatments (B: manure with dose 30 ton per hectare, B1: chicken manure, B2: quail manure, B3: cattle manure). Data was analyzed by $\mathrm{F}$ Test in $5 \%$ and followed by Honestly Significant Different/ HSD.

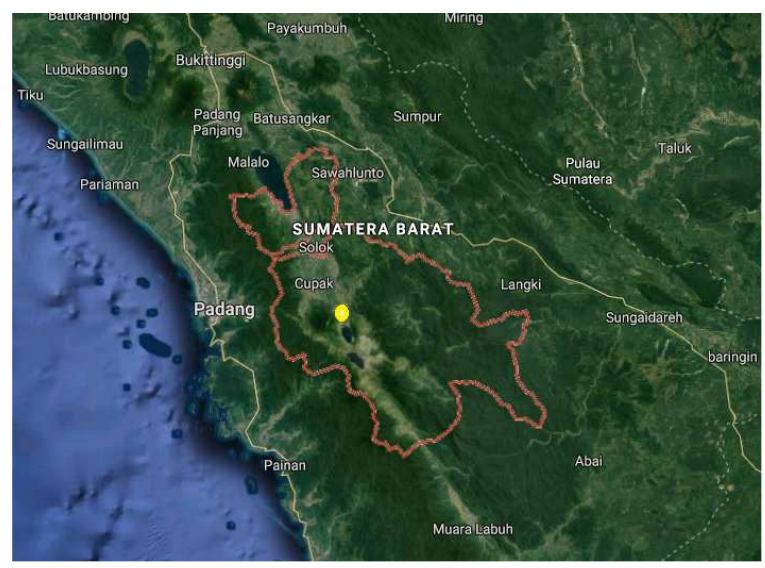

Fig. 1. Map of Solok Regency (red mark. Yellow dot : experimental location)

The potato seedlings were selected based from the similar size and uninfected by pest and disease. The seedlings were stored for 2 months until the shoot appeared. The seedlings which have 3 shoots and $2 \mathrm{~cm}$ in legth were planted in the field.

Application of manure (chicken, quail and cattle) in each plot was $17.64 \mathrm{~kg}$ per plot. The manure was sowed in the plot and stirred until homogeneous. Furthermore, the homogeneous soil was incubated for a week. For rhizobacteria treatments application was conducted by rinsing the potato seedlings with distillation water and then soaked in rhizobacteria suspension for 15 minutes and dried before planting.

The planting was conducted a week after the field was prepared. A hole with $7-10 \mathrm{~cm}$ in depth with planting space $30-40 \mathrm{~cm}$ were prepared before plantng. In each sole, a seedling that was treated by rhizobacteria was entered. The harvesting was conducted at 100 days after planting (d.a.p). Tubers that were taken from the soil were dried.

The variables observed were growth components (height of plant, tuber growth rate, length of root and Indole acetic acid analysis) and yield components (number of tuber per plant and per hectare and fresh weight of tuber ).

For tuber growth rate, the formula follows as:

$$
T G R=\frac{W 2 \text { of tuber }-W 1 \text { of tuber } m g / \text { day }}{t 2-t 1}
$$




\section{RESULT AND DISCUSSION}

\section{A. Growth components}

Height of plant is one of important component for plant growth. The result showed that the interaction between manure and rhizobacteria siolate to plant height (Table 1). The plant height of potato was influenced by environmental factor such as rainfall. During the experiment, the rainfall average of location was high (148 $\mathrm{mm} / \mathrm{month})$. This condition caused the plant growth was not optimal. In early growth until 40 d.a.p, the rainy season occured so that the sunlight for plant was not enough for photosynthesis and caused the plant heigh was not optimal. Appropriate temperature for potatao plant growth is was $1,500 \mathrm{~mm} /$ year or $125 \mathrm{~mm} /$ month [24].

Photosynthesis process was influenced by sunlight intensity. Sunlight intensity influenced stomata activity to absorb $\mathrm{CO}_{2}$. Availability of $\mathrm{CO}_{2}$ was source of carbohydrate synthesis so that it influenced for plant growth. The sunlight in vegetative and generative stages was determined by green leaves synthesis, stomata activity, nutrients absorption, respiration rate and protoplasm flow [25].

TABLE I

Plant Height Of Red Potato In 9 WeEks After Planting Based ON RHIZOBACTERIA ISOLATES AND MANURE (CM)

\begin{tabular}{|l|c|c|c|c|}
\hline \multirow{2}{*}{$\begin{array}{c}\text { Rhizobacteria } \\
\text { isolates }\end{array}$} & \multicolumn{3}{|c|}{ Manure (30 ton/hectare) } & \multirow{2}{*}{$\begin{array}{c}\text { Averag } \\
\text { e }\end{array}$} \\
\cline { 2 - 4 } & Chicken & Quail & Cattle & 34.60 \\
\hline Without siolate & 34.87 & 35.01 & 33.93 & 34.53 \\
\hline A2.1b2 & 35.57 & 37.73 & 35.43 & 36.24 \\
\hline A3.1a5 & 37.29 & 32.43 & 33.37 & 33.61 \\
\hline B1.2a2 & 39.59 & 31.23 & 36.50 & 34.91 \\
\hline Average & 36.81 & 34.10 & 33.62 & \\
\hline CD $=10.38 \%$ & & & & \\
\hline
\end{tabular}

The increasing of plant height was closely related to $\mathrm{P}$ absorption. Higher absorbed $\mathrm{P}$ by plant, the plant grew higher. This condition due to was a essential element to support plant height such as photosynthesis process, respiration, transfer and storage of energy, division and development of cell. $\mathrm{P}$ was assumed as important part of plant nutrient so that the availability of $\mathrm{P}$ in soil was significant in supporting plant height.

According the rhizobacteria isolates and manure application, the rate of plant growth from 4 weeks after planting (WAP) is shown in Figure 2 and Figure 3. The figure 2 showed that the plant height increased linearly every week followed the plant age untill optimum limit in 9 WAP. In 9 WAP, the plant growth stopped due to the plant entered vegetative stage. The potato plant in generative phase showed the physiology characteristics such as plant height stopped and the leaves were yellowing. The increasing of plant height was related to the increasing of number and division of cell. The plant height showed the activity of xylem formation and enlargement of cells. This activity caused the cambium pushed out and the new cells formed in outer layers so that the plant height increased.

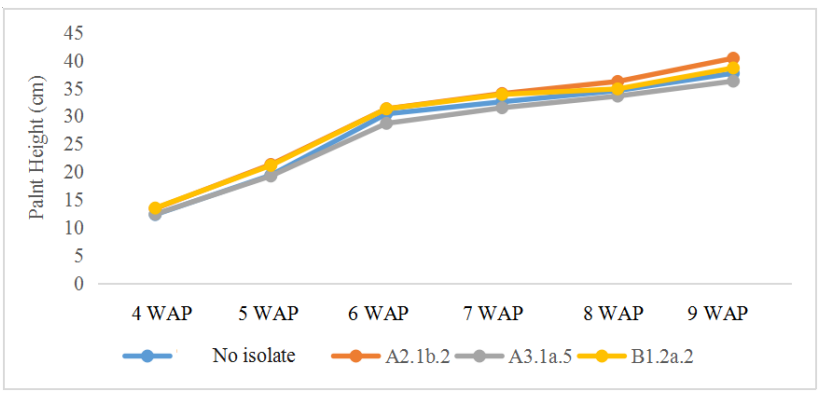

Fig. 2. The development of red potato plant height from 4 weeks after planting (WAP) to 9 WAP according the rhizobacteria isolates

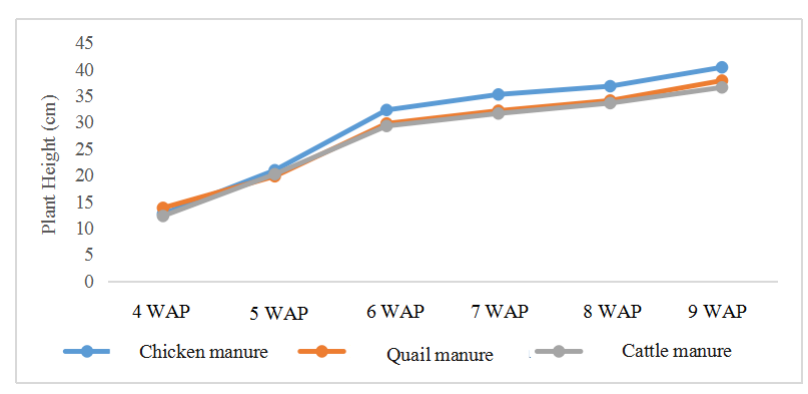

Fig. 3. The development of red potato plant height from 4 weeks after planting (WAP) to 9 WAP according the manure.

Sunlight affected the soil temperature and enzyme in plant. In appropriate temperature, enzyme in plant stimulated plant growth so that the mass production and light was absorbed by leaves to undertake the photosynthesis increases. The photosynthate was produced by plant influenced the plant growth, including height. The high temperature of soil could increase plant height of potato [26].

Manure was nutrients source for plant and soil microbes. Its existence could increase the root growth. Manure could increase the microbe activity in soil and repaired the soil structure so that it facilitated the root elongation. Some essential nutrients to support the plant growth such as N, P and $\mathrm{K}$ were contained in manure. These nutrients function were closely related to photosynthesis. $\mathrm{N}$ is macro essential element and built up $1.5 \%$ of plant weight and played a role as protein formation [27].

Other growth component to analyzed in this experiment was tuber growth rate (TGR). In this parameter, the interaction between manure and rhizobacteria siolate also did not affect the TGR (Table 2). TGR described the the rate of assimilate accumulation, fulfillment of tuber and the ability of source to supply assimylate to tuber. TGR was influenced by temperature due to it determined the enzyme performance in plant metabolism process. Photosynthesis underwent maximally at $24^{\circ} \mathrm{C}$ and if the temperature was above it, decreasing of tuber wieight occured [28].

High temperature effect also depended to the plant growth stage. Earlier plants to be exposed by high temperature, the negative effect was more to plant and tuber. High temperature activated several enzymes that inhibited conversion of glucose to starch so that the TGR decreased and length of tuber fulfillment was short [29]. 
TABLE III

Tuber Growth Rate Of Red Potato In 9 WeEKS AFter Planting BASED ON RHIZOBACTERIA ISOLATES AND MANURE (MG/DAY)

\begin{tabular}{|l|c|c|r|c|}
\hline \multirow{2}{*}{$\begin{array}{c}\text { Rhizobacteria } \\
\text { isolates }\end{array}$} & \multicolumn{3}{|c|}{ Manure (30 ton/hectare) } & \multirow{2}{*}{ Average } \\
\cline { 2 - 4 } & Chicken & Quail & Cattle & \\
\hline Without siolate & 1.20 & 1.52 & 1.58 & 1.43 \\
\hline A2.1b2 & 2.67 & 1.74 & 1.46 & 1.96 \\
\hline A3.1a5 & 0.79 & 1.41 & 2.28 & 1.49 \\
\hline B1.2a2 & 2.12 & 1.74 & 1.49 & 1.78 \\
\hline Average & 1.60 & 1.70 & 1.67 & \\
\hline CD $=7.42 \%$ & & & & \\
\hline
\end{tabular}

The other factor influenced the TRG was photosynthesis. High hotosynthesis rate sufficed the photosynthate requirement for growth and development of plant. Photosynthate was translocated to all parts of plant, included tuber. The fulfillment process occured at rainy season and it caused the sunlight absorption was unoptimal and photosynthesis rate was inhibited [30].

Nutrients in manure also affected the TGR. Chicken manure contained high nutrients such as N,P and K. High nutrient content caused growth rate was faster so that more photosynthate was used for tuber fulfillment. Beside that, chicken manure had advantage in availability rate of nutrient so that it always showed the best response in early first season [31].

TGR also was influenced by competition between canopy and plant root. At tuber growth stage, high competition occured between tuber and shoot of plant that grew together and play a role as sink. The competition stopped when the stover growth was maximum and just tuber played a role as sink. At this stage, stover played a role as source [32].

Root played important role for growth and yield of plant. In this experiment, the interaction between rhizobacteria and manure did not affect the plant root (Table 3). Plant root played a essential function such as plant standing, nutrient and water absorption and food storage. Root develompent and its ability to absorb nutrient incerased the growth and develompent of plant. Root had hairs in helping to absorb water and nutrients. Longer root caused more hairs and the water and nutrients absorption was optimal. Root development was also influenced by bacteria in rhizosphere such as Bacillus sp., a bacteria could dissolve phosphate so that could increase the $\mathrm{P}$ availability in soil and it was plant growth indicator [33][34].

One of $\mathrm{P}$ role in plant growth was root development stimulant. The maximum of $\mathrm{P}$ absorption by plant root and photosynthate use for growth and development of root increased TGR and plant height of red potato. This was caused by more phosphate solvent bacteria provided $\mathrm{P}$ for plant, the plant could stimulate root development and root formation so that the absorption availability increased [35].

In manure, there were nutrients and microbes that could soil fertility so that root plant was easier to penetrate the soil. Long roots increased the water and nutrients absorption. Banana plant in hydroponic, Plant Growth Promoting Rhizobacteria (PGPR) could increase volume and root length, plant height (42-50\%), leaf width (128-134\%), chlorophyll (25-33\%) and dry weight [36]. Rhizobacteria that was applied and soil microbes also incerased root length. In tomato plant, rhizobacteria application could increase plant height, plant biomass, length of root, number of fruit and fresh weight [37]. Addition of organic matter such as manure could repair soil structure by forming bigger soil granules by soil microorganisme in organic matter. The pattern of root spread was influenced by temperature, aeration, water availability and nutrients. Root well developed to cause optimal growth [38][39].

TABLE IIIII

Length Of Root Of Red Potato In 9 WeEks After Planting Based ON RHIZOBACTERIA ISOLATES AND MANURE (CM)

\begin{tabular}{|l|c|c|c|c|}
\hline \multirow{2}{*}{$\begin{array}{c}\text { Rhizobacteria } \\
\text { isolates }\end{array}$} & \multicolumn{3}{|c|}{ Manure (30 ton/hectare) } & \multirow{2}{*}{ Average } \\
\cline { 2 - 4 } & Chicken & Quail & Cattle & \\
\hline Without siolate & 29.67 & 39.67 & 36.67 & 35.33 \\
\hline A2.1b2 & 40.00 & 38.33 & 31.83 & 36.72 \\
\hline A3.1a5 & 35.00 & 35.83 & 41.00 & 37.28 \\
\hline B1.2a2 & 36.77 & 32.67 & 34.00 & 34.48 \\
\hline Average & 35.36 & 36.63 & 35.88 & \\
\hline CD =20.15\% & & & & \\
\hline
\end{tabular}

According the rhizobacteria isolates and manure application, the increasing of length of root from 5 WAP until 9 WAP can be seen in Figure 4 and Figure 5.

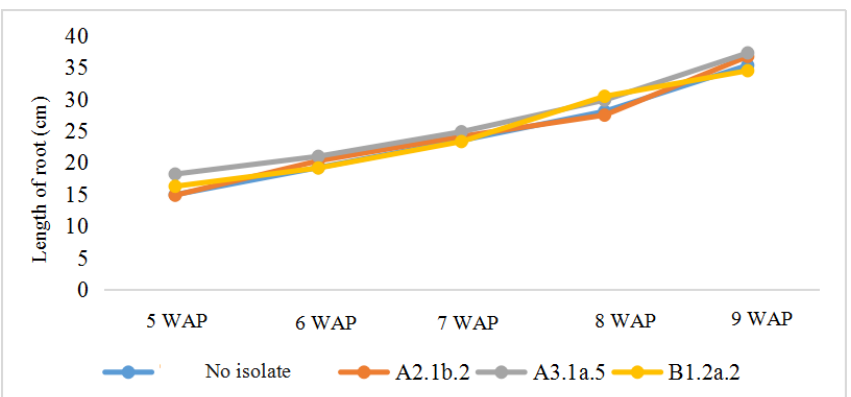

Fig. 4. The development of length of red potato root from 4 weeks after planting (WAP) to 9 WAP according rhizobacteria

The figure 4 showed that the length of root increased every week. This result due to the soil microbes supported the growth and development process of root. The length of root was affected by nitrogen fixing bacteria and phosphate solvent bacteria in root zone. One of bacteria was Azetobacter sp., a type of bacteria that could produce plant stimulating substance such as acetic indole acid, a chemical compound that could stimulate root growth.

In manure application (Figure 5), the root growth significantly increased every week. It was caused by the organic matter in soil could increase the root activity. Higher organic matter content in soil, the soil density decreased so that the root growth well developed.

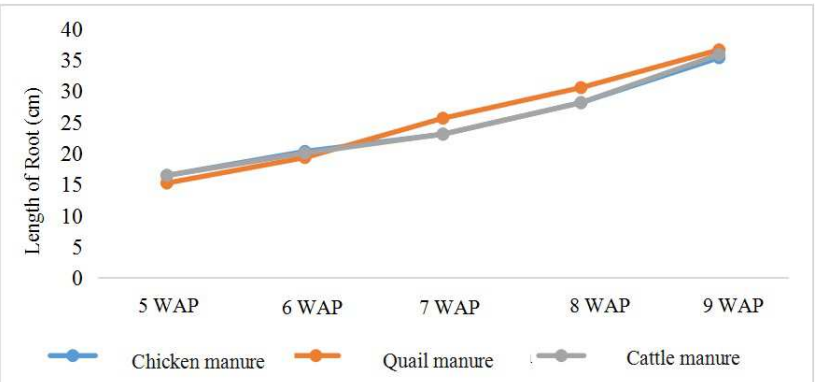

Fig. 5. The development of length of red potato root from 4 weeks after planting (WAP) to 9 WAP according manure 
Indole acetic acid (IAA) was a hormome that regulated cell development, stimulated flowering and root formation and increased the enzyme activity so that it could increased quality of yield. One of organisme could produce IAA was rhizobacteria [40]. The result showed that IAA on red potato plant was not influenced by interaction between manure and rhizobacteria isolates (Table 4). This result indicated that the application manure and rhizobacteria in same time did not affect IAA in red potato plant.

IAA production by rhizobacteria depended on examined isolate and its ability in colonizing rhizosphere. The ablity of rhizobacteria to increase growth, yield and seedling quality was closely related to its ability to synthesize growth hormone such as indole asetic, indole butyric acid and gibberellin, fixed $\mathrm{N}$ so that rendered double advantages for plant. Inoculation of Pesudomonas sp. in corn stimulated IAA. IAA increased in leaf tissue and root [41][42].

TABLE IV

INDOle ACETIC ACID Of Red PotATo In 9 WeEks After Planting BASED ON RHIZOBACTERIA ISOLATES AND MANURE (PPM)

\begin{tabular}{|l|c|c|c|c|}
\hline \multirow{2}{*}{$\begin{array}{c}\text { Rhizobacteria } \\
\text { isolates }\end{array}$} & \multicolumn{3}{|c|}{ Manure (30 ton/hectare) } & \multirow{2}{*}{ Average } \\
\cline { 2 - 4 } & Chicken & Quail & Cattle & \\
\hline Without siolate & 0.25 & 0.18 & 0.14 & 0.19 \\
\hline A2.1b2 & 0.14 & 0.33 & 0.10 & 0.19 \\
\hline A3.1a5 & 0.18 & 0.27 & 0.28 & 0.24 \\
\hline B1.2a2 & 0.10 & 0.22 & 0.48 & 0.26 \\
\hline Average & 0.16 & 0.25 & 0.25 & \\
\hline
\end{tabular}

PGPR produced IAA, a hormone could induce plant resistant to pests and diseases. IAA that produced by Pseudomonas group could increase plant growth and it induced the health plant. It substituted $\mathrm{N}$ by taking $\mathrm{N}$ from air and dissolved phosphate from complex compound intp simple compound. Rhizobacteria activity in rhizosphere induced plant resistance. The activity covered N,P,K availability, growth hormone, antibiotic production, a compound as toxic for pathogens. The health plant induced the resistance to pests and diseases [43].

\section{B. Yield components}

Tuber is main yield component in red potato plant. Number of tuber indicated the quality of potato plant. The result showed that the interaction between manure and rhizobacteria isolates did not affect the number of tuber (Table 5). The effect occrued in average of manure application.

Number of tuber was influenced by the rhizobacteria ability to increase the growth and yield of plant and nutrients absorbed by plant. Rhizobacteria could provide nutrients for increasing soil fertility and yield quality by increasing of biology activity that related to physical and chemical characteristicsof of soil. Rhizobacteria could colonize rhizosphere and inside part of cell and stimulated growth by increasing primary nutrients supply [44].

Manure had high nutrient content that could increase cell division rate. More cells resulted bigger tubber or more tubers. Size of tuber was accumulation of plant photosynthate during its life. Seedling potato size was not related to tuber size. Rhizobacteria was highly aggressive to colonize rhizosphere and also played a role as bio-fertilizer and bio-pesticide [16]. Beside that, the tuber size was also influenced by plant spacing. If the planting space surpassed minimum limit, tubers that harvested was unoptimal. Narrow plant spacing caused no space for stolon to develop. Planting space was originally provided a space for root plant to well develop and no competition occured [45].

TABLE V

Number Of Tuber Per Plant Of Red Potato In 9 Weeks After Planting BASEd ON RHIZOBACTERIA IsOlATES AND MANURE (MG/DAY)

\begin{tabular}{|l|c|c|c|c|}
\hline \multirow{2}{*}{$\begin{array}{c}\text { Rhizobacteria } \\
\text { isolates }\end{array}$} & \multicolumn{3}{|c|}{ Manure (30 ton/hectare) } & \multirow{2}{*}{ Average } \\
\cline { 2 - 4 } & Chicken & Quail & Cattle & \\
\hline Without siolate & 10.08 & 8.20 & 8.67 & 9.22 \\
\hline A2.1b2 & 10.04 & 10.07 & 8.00 & 9.50 \\
\hline A3.1a5 & 10.07 & 8.33 & 8.80 & 9.07 \\
\hline B1.2a2 & 10.60 & 10.13 & 8.80 & 9.84 \\
\hline Average & $10.47 \mathrm{~A}$ & $9.18 \mathrm{~B}$ & $8.80 \mathrm{~B}$ & \\
\hline CD =15.85\% & & & & \\
\hline
\end{tabular}

Note : numbers followed by uppercase in same row are significantly different according HSD test in 5\%

Number of tuber was also influenced by the ablity of of plant to provide nutrients that could be absorbed by plant to suffice nutrients requirement. The difference of number of tuber in manure treatment due to the nutrient content and maturity of each type of manure was different [38]. The ability of rhizobacteria isolates and manure to accumulate availability nutrients for plant growth, including photosynthesis and respiration, it increases assimylate production [46]. After undergoing development stage, photosynthate translocation was focused to tuber fulfillment. Number of tuber was infuenced by stolon ability to produce tuber [44].

Number of tuber affected the fresh weight of tuber of potato. Generally, interaction between manure and rhizobacteria did not affect fresh weight of potato. The different occured in manure and rhizobacteria application. For manure application, chicken and cattle manure was the best treatment and for rhizobacteria, isolate $\mathrm{A} 2.1 \mathrm{~b} 2$ and B1.2a2 were the best treatment (Table 6). It described the single application of rhizobacteria isolates affected the tuber fresh wieght. In eggplant, rhizobacteria isolates could increase growth and productivity (13.72 ton/hectare). The other report reported that manure and rhizobacteria increased corn productivity.

TABLE VI

Tuber Fresh Weight Per Plant Of Red Potato In 9 Weeks After Planting BASEd On Rhizobacteria IsOlates AND MANURe (KG)

\begin{tabular}{|l|c|c|c|c|}
\hline \multirow{2}{*}{$\begin{array}{c}\text { Rhizobacteria } \\
\text { isolates }\end{array}$} & \multicolumn{3}{|c|}{ Manure (30 ton/hectare) } & \multirow{2}{*}{ Average } \\
\cline { 2 - 4 } & Chicken & Quail & Cattle & \\
\hline Without siolate & 0.64 & 0.52 & 0.64 & $0.60 \mathrm{a}$ \\
\hline $\mathrm{A} 2.1 \mathrm{~b} 2$ & 0.74 & 0.67 & 0.73 & $0.71 \quad \mathrm{~b}$ \\
\hline $\mathrm{A} 3.1 \mathrm{a} 5$ & 0.72 & 0.49 & 0.61 & $0.60 \mathrm{a}$ \\
\hline $\mathrm{B} 1.2 \mathrm{a} 2$ & 0.81 & 0.71 & 0.74 & $0.75 \quad \mathrm{~b}$ \\
\hline Average & $0.72 \mathrm{~A}$ & $0.59 \mathrm{~B}$ & $0.68 \mathrm{~A}$ & \\
\hline CD $=17.61 \%$ & & & & \\
\hline
\end{tabular}

Note : numbers followed by uppercase in same row and lowercase in same coloumn are significantly different according HSD test in 5\%

Fresh weight of tuber was accumulation of each tuber. Best fresh weight occured in chicken manure application. This condition was caused by the manure contained higher nutrient content. Availability of nutrient was well absorbed by plant and supported by water availability as 
transportation media of nutrient and assimilate so that it increased growth and yield of plant. Nutrient requirement, water availability for plant determined increasing of plant fresh weight [46]. Plant fresh weight depended on water content in plant tissue and $80 \%$ of fresh weight was water [20][27]. The presence of rhizobacteria that was applied could increase nutrient absorption. Rhizobacteria could increase the growth and productivity of crops. Rhizobacteria also could mobilize various nutrients and synthesized and changed plant stimulant phytohormone [31]. Availabilty nutrients were used by plant to develop through photosynthesis process. Rhizobacteria could increase nutrients absorption so that it increased the photosynthesis growth and photosynthate. Application of rhizobacteria form Bacillus sp. group could increase tomato yield. [47].

For tuber weight per hectare, interaction between manure and rhizobacteria did not affect the plant growth. The difference occured in manure and rhizobacteria application. For manure, chicken manure was best treatment and for rhizobacteria isolate, all isolates affected the tuber weight per hectare (Table VII). The result showed that single factor affected the tuber weight per hectare. Rhizobacteria played a role as stimulant of growth and plant production increasing through several mechanism such as $\mathrm{N}$ fixation, phosphate solvent and produced plant growth hormone (IAA, gibberellin and cytokinin) [48].

The application of organic matter could repair soil structure, increased cation exchange capacity and maintained water in soil so that it could increase productivity and quality of tuber. Application 2 ton/ hectare of cattle manure could produce 8.6 ton of potato and application of manure to potato plant resulted better yield than without application.

\section{TABLE VII}

Tuber Weight Per Hectare Of Red Potato In 9 Weeks After

PLANTING BASED ON RHIZOBACTERIA IsOlates AND MANURE (TON)

\begin{tabular}{|l|c|c|c|c|}
\hline \multirow{2}{*}{$\begin{array}{c}\text { Rhizobacteria } \\
\text { isolates }\end{array}$} & \multicolumn{3}{|c|}{ Manure (30 ton/hectare) } & \multirow{2}{*}{ Average } \\
\cline { 2 - 4 } & Chicken & Quail & Cattle & \\
\hline Without siolate & 10.55 & 8.59 & 9.99 & $9.71 \mathrm{~b}$ \\
\hline A2.1b2 & 13.05 & 11.10 & 10.83 & $11.66 \mathrm{a}$ \\
\hline A3.1a5 & 11.67 & 8.87 & 9.97 & $10.17 \mathrm{a}$ \\
\hline $\mathrm{B} 1.2 \mathrm{a} 2$ & 11.67 & 12.23 & 10.56 & $11.48 \mathrm{a}$ \\
\hline Average & $11.73 \mathrm{~A}$ & $10.20 \mathrm{~B}$ & $10.33 \mathrm{~B}$ & \\
\hline $\mathrm{CD}=12.71 \%$ & & & & \\
\hline
\end{tabular}

Note : numbers followed by uppercase in same row and lowercase in same coloumn are significantly different according HSD test in 5\%

\section{CONCLUSIONS}

Generally, interaction between manure and rhizobacteria did not affect growth and yield of red potato. The difference occured in for fresh weight per plant and tuber weight per hectare of red potato. Chicken manure was best treatment for fresh weight per plant and tuber weight per plant. All isolates of rhizobacteria affected the tuber weight per hectare of red potato.

\section{ACKNOWLEDGMENT}

We would like to thank to Dean of Faculty of Agriculture, Andalas University, Indonesia and all participants who helped this study.

\section{REFERENCES}

[1] J.L. Whitworth, R.A. Selstedt, A.A.G. Westra, P. Nolte, K. Duellman, S.K.R Yellareddygari, N.C. Gudmestad, " Symptom expression of mainstream and specialty potato cultivars to Bacterial ring root (Clavibacter sepedonicus) and evaluation of in-field detection," American Journal of Potato Reseacrh, vol. 96, issue 4, pp. 427-444, June 2019

[2] H. Kesaulya, Baharuddin, B. Zakaria, S.A. Syaiful, “ Morphological characteristics of potato (Solanum tuberosom L.) variety Hartapel origin south Buru-Moluccas," International Journal of Current Research in Bioscience and Plant Biology, vol. 2, issue 2, pp. 15-21, February. 2015

[3] C. Wibowo, K. Wijaya, G.H. Sumartono, E. Pawelzik, " Effect of potassium level on quality traits of Indonesian potato tubers," Asian Pasific Journal of Sustainable Agriculture Food and Energy, vol. 2, issue 1, pp. 11-16, March 2014

[4] K. A. Beals, " Potato, Nutrition and health ," American Journal of Potato Research, vol. 96, pp. 102-110, December 2018

[5] D.G. Omayio, G.O. Abong, M.W. Akoth, "A review of occurrence if glycoalkaloids in potato and potato products," Current Research in Nutrition and Food Science, vol. 4, issue 3, pp. 195-202, November 2018

[6] Food and Agricultural Organization of The United Nations (2014) [Online]. Available: http://faostat3.fao.org

[7] Statistics Indonesia, " Potato production in West Sumatera," Statistics Indonesia, July 2019

[8] J. Lachman, K. Hamouz, " Red and purple coloured potatoes as a significant antioxidant source in humant nutrition," Plant Soil Environment, vol. 51, issue 11, pp. 477-482, June 2005

[9] Statistics Indonesia, "Potato production of Indonesia", Statistics Indonesia, July 2019

[10] Badan Pusat Statitik Kabupaten Solok, “ Produksi kentang Kabupaten Solok 2018,’ Badan Pusat Statistik, Juli 2019

[11] A.C. Gange, K. R. Gadhave, " Plant growth promoting rhizobacteria promote plant size inequality," Scientific Reports, vol. 8, pp. 1-10, September 2018

[12] R. Backer, J.S Rokem, G. Ilangumaran, J. Lamont, D. Praslickova, E. Ricci, S. Subramanian, D.L. Smith, " Plant-Growth Promoting Rhizobacteria: Context, mechanisms of action, and road map to commercialization of biostimulants for sustainable agriculture," Frontiers in Plant Science, vol. 9, pp. 1-17, October 2018

[13] M. Ahemad, M. Kibret, "Mechanisms and Applications of plantgrowth promoting rhizobacteria : Current perspective, " Journal of King Saudi University, vol. 26, pp. 1-20, May 2013

[14] A. Gunez, K. Karagoz, M. Turan, R. Kotan, E. Yildirim, R Cakmakci, F. Sahin, " Fertilizer Efficiency of Some Plant Growth Promoting Rhizobacteria for Plant Growth, " Reserach Journal of Soil Biology, vol. 7, issue 2, pp. 28-45, June 2015

[15] R.J. Akinrinrola, G.Y. Yuen, R.A. Drijber, A.O. Adesemoye, " Evaluation of Bacillus strains for plant growth promotion and predictability of efficacy by In-vitro physiological traits," International Journal of Microbiology, vol. 2018, pp. 1-11, October 2018

[16] J.K. Vessey, “ Plant growth promoting rhizobacteria as biofertilizers, “Plant and Soil, vol. 225, issue 2, pp. 571-586, August 2003

[17] M. Veerapagu, K.R. Jeya, R. Priya, N. Vetrikodi, “ Isolation and screening of plant growth promoting rhizobacteria from rhizosphere of chilli," Journal of Pharmacognosy and Phyrochemistry, " vol. 7, issue 4, pp. 3444-3448, June 2018

[18] J.F.M. Passos, P.B. Costa, M.D. Costa, G.R. Zaffari, G. Nava, J.I Boneti, A.M.R. Oliveira, L.M.P. Passaglia, " Cultivable bacteria isolated from apple trees cultivated under different crop systems: Diversity and antagonistic activity against Colletotrichum gloeosporioides, “ Genetics and Molecular Biology, vol. 37, issue 3, pp. 560-572, September 2014

[19] A.T. Wahyudi, J.A. Priyanto, R. Afrista, D. Kurniawati, R.I. Astuti, A. Akhdiya, " Plant growth promoting activity of Actinomycetes Isolated form soybean rhizosphere, Journal of Biological Science, vol. 19, issue 1, pp. 1-8, January 2019

[20] H. Wang, H. Li, M. Zhang, Y. Song, J. Huang, H. Huang, M. Shao, Y. Liu, " Carbon dots enhance the nitrogen fixation activity of Azetobacter chroococcum, “ Applied Materials and Interfaces, vol. 10, issue 19, pp. 16308-16314, May 2018

[21] H. Yolcu, M. Turan, A. Lithourgidis, R. Camakci, A. Koc, “ Effects of plant growth-promoting rhizobacteria and manure on yield and quality characteristics of Italian ryegrass under semi arid conditions, 
“Australian Journal of Crop Science, vol. 5, issue 13, pp. 1730-1736, December 2011

[22] S.T. Mahabub, M.S.H. Khan, H.E.M.K. Mazed, S. Sarker, M.H Tareque, "Effect of cow manure on growth, yield and nutrient content of Mungbean, " Asian Research Journal of Agriculture, vol. 2, issue 1, pp. 1-6, October 2016

[23] T. Supaddit, L.Sangla, N. Sunthorn, " Effects of pelleting on fertilizer quality of quail litter, "African Journal of Agricultural Research, vol. 6, issue 27, pp. 5940-5947, October 2011

[24] K. Rymuza, E. Radzka, T. Lenartowicz, " Effect of weather condition on early potato yields in East-Central Poland," Communication in Biometry and Crop Science, vol. 10, issue 2, pp. 65-72, August 2015

[25] U. Flugge, P. Westhoff, D. Leister, " Recent advances in understanding photosynthesis," F1000 Research, vol. 5, pp. 1-10

[26] S.C.v. Martins, K.C. Detmann, J.V. Reis, L.F. Pereira, L.M.V.P. Sanglard, M. Rogalski, F.M. Damatta, "Photosynthetic induction and activity of enzymes related to carbon metabolism: insights into the varying net photosynthesis rates of coffe sun and shade leaves, "Theoretical and Experimental Plant Physiology, vol. 25, issue 1, pp. 62-69, January 2013

[27] S.J. Leghari, N.A. Wahocho, G.M. Laghari, A.H. Laghari, G.M. Bhabhan, K.H. Talpur, T.A. Bhutto, S.A. Wahocho, A.A. Lashari, " Role of nitrogen for plant grwoth and development : A review, "Advances in Environmental Biology, vol. 10, issue 9, pp. 209-218, September 2016

[28] J.S. Hamdani, A. Nuraini, S. Mubarok, " The use of Paclobutrazol and shading net on growth and yield of potato 'medians' tuber of G2 in medium land in Indonesia, " Journal of Agronomy, vol. 17, issue 1, pp. 62-67, January 2018

[29] Y. Gao, L. Jia, B. Hu, A. Alva, M . Fan, “ Potato Stolon and tuber growth influenced by nitrogen," Plant Production Science, vo. 17, issue 2, pp. 138-143, August 2013

[30] W.Q Yu, Y.Q. Wang, Y. J. Wang, H. L. Zhang, B. Wang, Y. Liu, "Effect of precipitation and biomass accumulation and referring to splah erotion status in five typical evergreen tree species in humid moonson climatic region of subtropical hill-land, " Journal of Central South University, vol. 22, issue 10, pp. 3798-3805, October 2015

[31] C. Suh, S.S. Meka, A.F. Ngome, D.A. Neba, I.T. Kemngwa, A.D Sonkouat, D. Njualem, " Effect of organic and inorganic fertilizers on growth and yield of potato (Solanum tuberosom L.) in Western Highland of Cameroon, " International Journal of Development Research, vol. 5, issue 2, pp. 1-5 February 2015

[32] Moehninsi, D.A. Navarre, "Optimization of hairy root induction in Solanum tuberosum," American Journal of Potato Research, vol. 95, issue 6, pp. 650-658, December 2018

[33] C. Phandey, V.K. Bajpai, Y.K. Negi, I.A. Rather, D.K. Maheswari, " Effect of plant growth promoting Bacillus spp. On nutritional properties of Amaranthus hypochondriacus grains, " Saudi Journal of Biological Science, vol. 25, issue 6, pp. 1066-1071, March 2018

[34] Y Cao, H. Pi, P. Chandrangsu, Y. Li, Y. Wang, H. Zhou, H. Xiong, J.D. Helman, " Antagonism of Two Plant-Growth Promoting Bacillus velezensis Isolates Against Ralstonia solanacearum and Fusarium oxysporum," Scientific reports, vol. 8, pp. 1-14, January 2018.
[35] J. Nyiraneza, B. Bizimungu, A.J. Messiga, K.D. Fuller, S.A..E Fillmore, Y. Jiang, "Potato yield and phosphorus use efficiency of two new potato cultivars in New Brunswick, Canada," Canadian Journal of Plant Science, vol. 97, pp. 784-795, January 2017

[36] R.M. Gamez, F. Rogriguez, S. Ramirez, Y. Gomez, R. Agarwala, D. Landsman, L.M. Ramirez, " Genome sequence of banana plant growth promoting rhizobacterium Pesudomonas flourescens PS006, "Genome Announcements, vol. 4, issue 3, pp. 1-2, May 2016

[37] A. Nookaraju, S. Kappachery, J.W. Yu, S.W. Park,” Rhizobacteria Influence Potato Tuberization Through Enhancing Lipoxygenase Activity, “ American Journal of Potato Research, vol. 88, pp. 441449, October 2011

[38] E.E. Oldfield, M.A. Bradford, S.A. Wood, " Global meta analysis of the relationship between soil organic matter and crops yield, "Soil, vol. 5, pp. 15-35, May 2019

[39] D.A. McGranahan, A.L. Daigh, J.J. Veenstra, D.M. Engle, J.R. Miller, D.M. Debinski, "Connecting soil organic carbon and root biomass with and use vegetation in temperature grassland, "The scientific World Journal, vol. 2014, pp. 1-9, October 2014

[40] M. Li, R. Guo, F. Yu, X. Chen, H. Zhao, H. Li, J. Wu, " Indole-3 acetic acid biosynthesis pathways in the plant beneficial bacterium Arthrobacter pascens ZZ21," International Journal of Molecular Sciences, vol. 19, issue 2, pp. 443, February 2018

[41] A. Karnwal, A. Dohroo, " Effect of maize root exudates on indole-3acetic acid production by rice endophytic bacteria under influence of L-tryptophan ," F1000 Research, vol. 7, issue 112, pp. 1-9, February 2018

[42] A. Karnwal, " Production of indole acetic acid by flourescent Pesudomonas in the presence of L-Tryptophan and rice root exudates, “ Journal of Plant Pathology, vol. 91, issue 1, pp. 61-63, March 2009

[43] T. Jayasudha, R. Rangeshwaran, N.V. Vajid, " Relationship between indole acetic acid production by flourescent Pesudomonas and plant growth promotion," Journal of Biological Control, vol. 24, issue 4 pp. 349-359, August 2010

[44] N.R. Knowles, L.O. Knowles, " Manipulating stem number, tuber set, and yield relatiosnhip for nothern and southern grown potato seed lots, " Crop Science, vol. 46, pp. 284-296, January 2006

[45] L.L.S.R. Sales, S.O. Jadoski, C.D.G. Maciel, A. Suchoronczek, C.J. Jadoski, " Management of ridging and plant spacing on yield and characteristics of potato tubers, " Brazilian Journal of Applied Technology for Agricultural Science, vol. 8, issue 1, pp. 15-25, April 2015

[46] Y. Bashan, L.E.D. Bashan, “ Fresh-weight measurements of roots provide inaccurate estimates of the effects of plant growth-promoting bacteria on root growth: a critical examination, "Soil Biology and Biochemistry, vol. 37, pp. 1795-1804, February 2005

[47] K.A. Tsukanova, V.K. Chebotar, J.J.M. Meyer, T.N. Bibikova, " Effect of plant growth promoting rhizobacteria on plant hormone homeostatis, " South Africa Journal of Botany, vol. 113, pp. 91-102, November 2017

[48] M.C. Enebe, O.O. Babalola, " The influence of plant promoting rhizobacteria in plant tolerance to abiotic stress : a survival strategy, "Applied Microbiology and Biotechnology, vol. 102, issue 18, pp. 7821-7835, July 2018 